\title{
ALTERNATIVNA KRUŽNA RASKRIŽJA KAO MJERA POBOLJŠANJA SIGURNOSTI PROMETA NA RASKRIŽJIMA
}

\section{ALTERNATIVE TYPES OF ROUNDABOUTS AS A MEASURE TO IMPROVE TRAFFIC SAFETY AT INTERSECTIONS}

\author{
Sanja Šurdonja*, Ivan Rutko*, Aleksandra Deluka-Tibljaš*
}

\begin{abstract}
Sažetak
Dvotračna kružna raskrižja primjenjuju se kao rješenje koje povećava kapacitet raskrižja (u usporedbi s klasičnim i jednotračnim kružnim raskrižjem), ali istovremeno značajno smanjuje razinu prometne sigurnosti. Alternativna kružna raskrižja pokazala se kao „kompromis“ između većeg kapaciteta, u odnosu na jednotračna i bolje prometne sigurnosti, u odnosu na dvotračna kružna raskrižja. U radu je prikazana analiza primjene alternativnih kružnih raskrižja na lokaciji postojećeg dvotračnog kružnog raskrižja te višekriterijska analiza kao alat pri odabiru optimalne varijante.
\end{abstract}

Ključne riječi: alternativno kružno raskrižje, prometna sigurnost, kapacitet

\begin{abstract}
Two-lane roundabouts, the one-level intersection types, are used as a solution to increase the capacity of the intersection (in comparison to the classic and the onelane roundabout). However, at the same time they significantly reduce the level of traffic safety. Alternative roundabouts are a "compromise" for achieving higher capacity compared to one-lane, and better traffic safety compared to two-lane roundabouts. The paper presents the application of alternative roundabouts at the location of the existing two-lane roundabout and multi-criteria analysis as a tool in selecting the optimal variant.
\end{abstract}

Key words: alternative roundabout, traffic safety, capacity

\footnotetext{
* Sveučilište u Rijeci, Građevinski fakultet, Radmile Matejčić 3, 51000 Rijeka E-mail: \{sanja.surdonja, ivan.rutko, aleksandra.deluka\}@uniri.hr
} 


\section{Uvod}

U Hrvatskoj se posljednjih dva desetljeća kružna raskrižja primjenjuju kao rješenja u rekonstrukciji postojećih raskrižja u razini na kojima je uočen problem sigurnosti odvijanja prometa ili nedovoljnog kapaciteta.

Brojna istraživanja u svijetu su potvrdila da kružna raskrižja doprinose smanjenju broja prometnih nesreća i povećanju kapaciteta raskrižja [1, 2], dok se u posljednje vrijeme ističu i druge prednosti implementacije ovog tipa raskrižja, poput smanjenja emisije štetnih plinova i buke u zoni raskrižja [3]. Istraživanja [4] pokazuju da je broj prometnih nesreća na jednotračnim kružnim raskrižjima značajno manji nego na dvotračnim kružnim raskrižjima, iako su u tom pogledu i dvotračna kružna raskrižja sigurnija od ostalih klasičnih tipova raskrižja [5].

Dvotračna kružna raskrižja često su rješenje koje se primjenjuje prvenstveno kako bi se povećao kapacitet raskrižja. Međutim, brojna istraživanja su pokazala da se primjenom ovog tipa raskrižja ne postiže očekivano povećanje kapaciteta, dok se istovremeno razina prometne sigurnosti značajno smanjuje [6].

Problem niske razine prometne sigurnosti kao i nedovoljnog kapaciteta postojećeg raskrižja u posljednje vrijeme rješava se primjenom alternativnih kružnih raskrižja [7].

U radu je prikazana analiza mogućnosti primjene alternativnih kružnih raskrižja na mjestu postojećeg dvotračnog kružnog raskrižja na kojem je utvrđena niska razina prometne sigurnosti. Varijante rješenja analizirane su primjenom unaprijed definiranih kriterija te je odabrana optimalna varijanta kružnog raskrižja.

\section{Raskrižja u razini}

U cestovnoj mreži, raskrižja u razini (RUR) predstavljaju mjesta oblikovana i uređena na način da omogućavaju povezivanje različitih vrsta prometnica te funkcioniranje cestovnog prometa u istoj razini [8].

Neovisno analizira li se postojeće raskrižje ili se planira rekonstrukcija postojećeg, kao i gradnja potpuno novog raskrižja, nužno je pomno analizirati slijedeće kriterije [8]:

- sigurnost na raskrižju (provozna brzina, preglednost, broj konfliktnih točaka i sl.)

- kapacitet raskrižja

- provoznost mjerodavnog vozila kroz raskrižje.

Pored navedenih obveznih kriterija, analize po potrebi mogu obuhvatiti i dodatne kriterije:

- utjecaj raskrižja na okoliš

- ekonomičnost rješenja. 
Raskrižja koja zadovoljavaju sve navedene kriterije smatraju se optimalnim rješenjima.

\subsection{Kružna i alternativna kružna raskrižja}

Kružna raskrižja, kao tip raskrižja u razini, sve češće nalaze svoju primjenu, bilo kod rekonstrukcije postojećih ili izgradnje novih raskrižja, budući da, u usporedbi s klasičnim raskrižjima u razini, ova raskrižja u pravilu osiguravaju veći kapacitet, sigurnija su (imaju manji broj konfliktnih točaka) te ujedno djeluju i kao mjera smirenja prometa.

U pravilu, danas se prilikom rekonstrukcije postojećih klasičnih raskrižja primjenjuju jednotračna kružna raskrižja, a iznimno i dvotračna kružna raskrižja. Dvotračna ili višetračna kružna raskrižja imaju jedan ili dva prometna traka na ulazu ili izlazu te kružni kolnički trak koji je u cijelosti ili samo djelomično izveden u dva (ili više) prometnih traka. Imaju i nešto veći kapacitet u odnosnu na jednotračna, ali zbog pojave točke preplitanja i križanja u kružnom kolniku, a koja ne postoji kod jednotračnih kružnih raskrižja, razina prometne sigurnosti im je značajno manja u odnosu na jednotračna kružna raskrižja te se njihova izvedba ne preporučuje u mnogim zemljama [9].

Jednotračno i dvotračno kružno raskrižje kao osnovni tipovi kružnih raskrižja imaju brojne prednosti nad klasičnim raskrižjima u razini, ali imaju i mana koje se kroz desetljeće pokušavaju otkloniti alternativnim tipovima kružnih raskrižja. Ovisno koji kriterij se detaljnije analizira, svaki alternativni tip kružnog raskrižja predstavlja povoljno rješenje u odnosu na promatrani kriterij.

Danas u svijetu postoji velik broj alternativnih kružnih raskrižja koja predstavljaju svojevrsnu kombinaciju jednotračnih i višetračnih kružnih raskrižja te eliminiraju nedostatke oba tipa kružnih raskrižje. Neki tipovi alternativnih kružnih raskrižja su već naveliko u upotrebi ili su u fazi analize njihove moguće primjene [10]:

- kružno raskrižje „hamburger“

- kružno raskrižje „dumb-bell“

- kružno raskrižje „dog-bone“

- kružno raskrižje "flower"

- turbo-kružno raskrižje i sl.

U nastavku su detaljnije prikazana dva tipa alternativnih kružnih raskrižja, turbo-kružno raskrižje i kružno raskrižje „flower“, a koja su predložena kao rješenja na mjestu postojećeg dvotračnog kružnog raskrižja Rujevica.

„Flower“ kružna raskrižja su raskrižja koja su još u fazi analiziranja prednosti i nedostataka njihove primjene (Slika 1). Ovaj tip alternativnih kružnih raskrižja obvezno bi trebao imati trake za desne skretače, koji 
samim time nisu obvezni ulaziti u kružno raskrižje, a ako i uđu, imaju ponovno mogućnost desnog skretanja na prvom izlazu [10].

$\mathrm{Na}$ ovaj se način smanjuje prometno opterećenje u samom kružnom toku te se povećava kapacitet samog raskrižja, ali i sigurnost za sve sudionike budući je značajno smanjen broj konfliktnih točaka raskrižja. Trake za desne skretače su fizički odvojene od samog kružnog toka. Sigurnost nemotoriziranih sudionika (pješaka i biciklista) je nešto manja zbog nešto veće brzine desnih skretača. Iako ovaj tip alternativnog kružnog raskrižja povećava kapacitet, veću pažnju potrebno je usmjeriti na brzine u raskrižju kako bi se osigurala dostatna prometna sigurnost svih sudionika [10]. Ovaj tip kružnog raskrižja je lako primjenjiv na mjestima postojećih dvotračnih kružnih raskrižja koja je potrebno rekonstruirati, a bez zauzimanja dodatnog okolnog prostora.
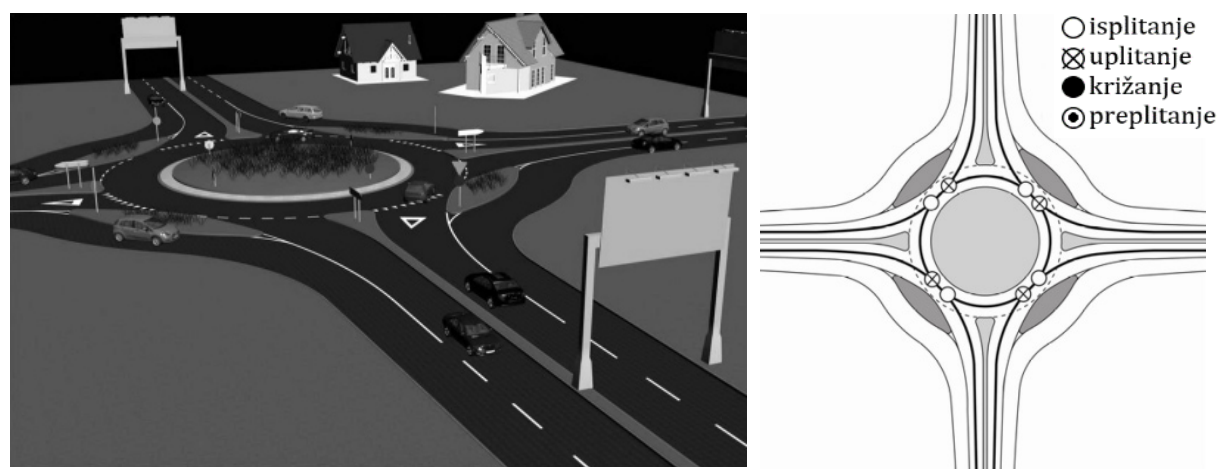

Slika 1. „Flower“ kružno raskrižje: simulacija raskrižja (lijevo) i konfliktne točke (desno) [10]

Turbo-kružno raskrižje je alternativno rješenje koje se često koristi kako bi se zamijenilo klasično dvotračno kružno raskrižje na kojem je niska razina prometne sigurnosti, odnosno povećao kapacitet jednotračnog kružnog raskrižja ili klasičnog raskrižja u razini. Turbo-kružna raskrižja mogu biti dvotračna ili trotračna, pri čemu su trake u kružnom dijelu kolnika fizički odvojene delineatorima (specifičnim rubnjacima), a koji se ne koriste kod drugih tipova kružnih raskrižja. Oni sprečavaju promjene traka u samom kružnom toku (preplitanje vozila), što povećava razinu sigurnosti prometa. Iako postoje točke križanja, vozač mora obratiti pažnju samo na vozila koja mu dolaze s lijeve strane u kružnom toku. Prije ulaska u kružni tok nužno je odabrati onu traku u kružnom toku za koju je prije vertikalnom i horizontalnom signalizacijom naznačeno da vodi prema željenom izlazu (Slika 2) [10, 11]. 

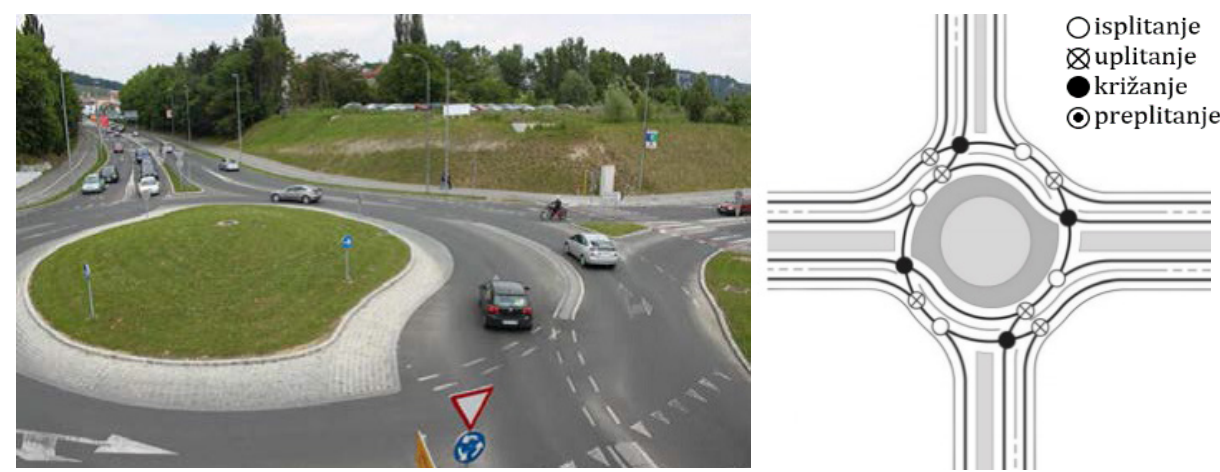

Slika 2. Turbo-kružno raskrižje: primjer raskrižja (lijevo) i konfliktne točke (desno) [10]

Zbog navedenog, ta se kružna raskrižja često nazivaju i „nepraštajuća“ kružna raskrižja budući da u nekim slučajevima, ukoliko vozač pogrešno odabere traku na ulazu u turbo-kružno raskrižja, nije moguća ispravka u samom kružnom toku jer turbo-kružna raskrižja u samom kružnom toku imaju trake koje ne omogućuju prestrojavanje ili preplitanje. Fizička odvojenost je u raskrižju prekinuta samo na mjestima dozvoljenog ulaska u unutarnji trak $[10,11]$.

U turbo-kružnim raskrižjima nema križanja na izlazima i preplitanja u kružnom toku pa je zbog toga i razina sigurnosti značajno veća u usporedbi s dvotračnim kružnim raskrižjem.

\section{Analiza postojećeg raskrižja Rujevica}

Postojeće raskrižje Rujevica četverokrako je dvotračno raskrižje, smješteno na sjeverozapadnom dijelu grada, te je jedan od glavnih ulaza u grad sa Riječke obilaznice, odnosno autoceste A7, što omogućuje vezu zapadnog dijela grada s istočnim i centrom grada te okolnim naseljima. Privozi raskrižja su (Slika 3) [12]:

- Privoz 1: Ulica Antuna Kosića Rika, lokalna cesta

- Privoz 2: supermarket Interspar, lokalna cesta

- Privoz 3: nova cesta prema naselju Viškovo, županijska cesta

- Privoz 4: izlaz s autoceste A7, državna cesta. 


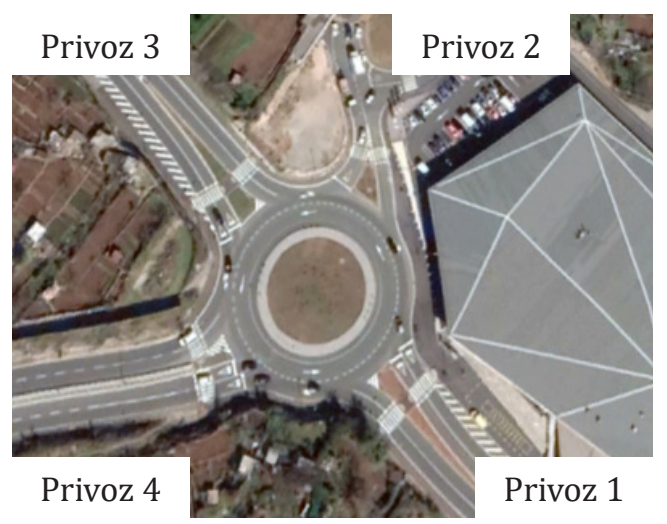

Slika 3. Postojeća situacija dvotračnog kružnog raskrižja Rujevica [13]

U neposrednoj blizini raskrižja nalaze se trgovački centar Interspar i nogometni stadion Rujevica, oba objekta koji značajno privlače i motorizirani promet i nemotorizirani promet.

\subsection{Analiza prometnih nesreća na raskrižju}

Analizirano raskrižje je već jednom rekonstruirano, i to iz klasičnog trokrakog raskrižja u dvotračno kružno raskrižje 2017. godine. Tada su analize prometnog opterećenja pretpostavile da će dvotračno kružno raskrižje zadovoljiti u pogledu kapaciteta, dok se potencijalne prometne nesreće nisu analizirale. Prema službenoj evidencije o prometnim nesrećama na kraju 2017. godine, dobivenoj od strane MUP-a Rijeka, na raskrižju je u samo godinu dana evidentirano 19 prometnih nesreća, od kojih jedna sa smrtnim posljedicama, te 18 nesreća s materijalnom štetom. Velik broj prometnih nesreća (10 nesreća) dogodio se zbog prestrojavanja u kružnom kolniku, dok je prema vrsti prometnih nesreća velik broj (10 nesreća) bočnih sudara vozila.

\subsection{Analiza prometnog opterećenja i brzina vozila}

Kako bi se utvrdilo prometno opterećenje na raskrižju, na 3 privoza raskrižju (svih osim privoza 2 - Interspar) postavljeni su brojači prometa koji kontinuirano bilježe promet tijekom 24 sata te je izvršeno i ručno brojanje prometa tijekom radnog tjedna. Vremenski uvjeti su bili stabilni, a na raskrižju nisu zabilježeni nikakvi događaji koji bi uzrokovali ometanje odvijanja prometa. Analizom svih triju brojača (Tablica 1) vidljivo je da je da je naopterećeniji privoz 3 (smjer iz Viškova), dok su brzine najveće na privozu 4 (izlaz sa obilaznice). Operativne brzine (i prosječna i V85) na 2 privoza su iznad ograničenja brzina [12]. 
Tablica 1.Prometno opterećenje i brzine vozila po privozima [12]

\begin{tabular}{|c|c|c|c|}
\hline & Privoz 1 & Privoz 3 & Privoz 4 \\
\hline dnevno opterećenje [voz/dan] & 9736 & 9858 & 7499 \\
\cline { 3 - 4 } vršno opterećenje [voz/sat] & 711 & 1274 & 776 \\
\hline Vavg [km/h] & 51 & 36 & 62 \\
\hline V85 [km/h] & 61 & 46 & 75 \\
\hline
\end{tabular}

\subsection{Analiza kapaciteta postojećeg raskrižja}

Kapacitet postojećeg raskrižja analiziran je koristeći računalni program SIDRA INTERSECTION. Kao ulazni podaci korišteni su podaci dobiveni ručnim brojanjem prometa, i to u popodnevnom vršnom satu (PVS), te podaci o geometriji raskrižja (broj, namjena i širine prometnih traka). Rezultati analize kapaciteta za postojeće stanje raskrižja (Slika 4) pokazuju da na svim privozima postoji velika rezerva u kapacitetu i da su razine uslužnosti na svim privozima odlične (A) ili vrlo dobre (B).

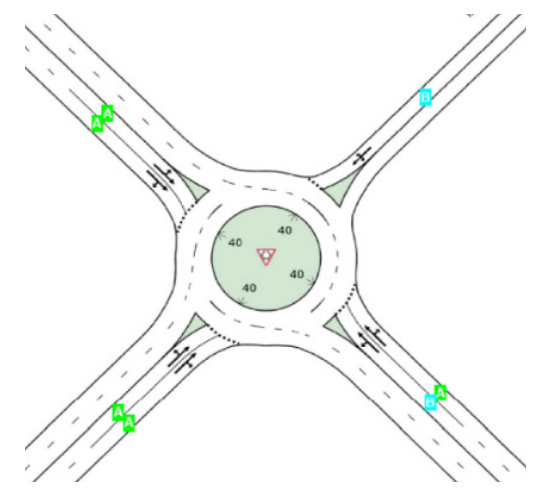

Slika 4. Razina uslužnosti za postojeće stanje raskrižja [12]

\subsection{Analiza preglednosti na postojećem raskrižju}

Preglednost na kružnom raskrižju analizirana je prema hrvatskim Smjernicama [9]. Iako se radi o dvotračnom kružnom raskrižju, za koje smjernice ne preporučuju niti daju upute za njegovo oblikovanje, analizirana je preglednost kao za slučaj jednotračnog kružnog raskrižja. Preglednosti koje je nužno osigurati na kružnim raskrižjima su [9]:

- prilazna preglednost

- preglednost na ulazu

- preglednost ulijevo

- preglednost u kružnom kolniku. 

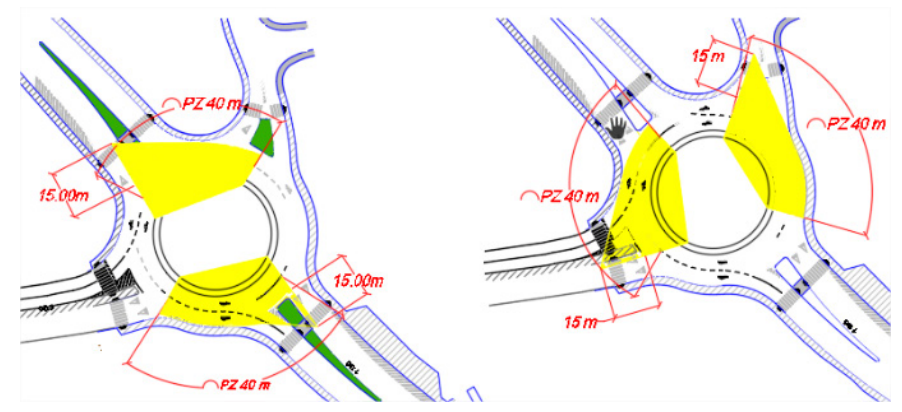

Slika 5. Preglednost ulijevo i preglednost u kružnom kolniku

Za svaki privoz analizirane su prve tri preglednosti, dok je, radi iste geometrije, za preglednost u kružnom kolniku dovoljna samo jedna provjera. Analiza provedenih preglednosti pokazala je da su na svim privozima (Slika 5) [12] zadovoljene sve potrebne preglednosti prema Smjernicama.

\section{Varijantna rješenja rekonstrukcije raskrižja Rujevica}

Provedena analiza postojećeg stanja na dvotračnom kružnom raskrižju Rujevica ukazala je prvenstveno na problem sigurnosti na tom raskrižju. Velik broj konfliktnih točaka (prvenstveno preplitanja i križanja) rezultirao je velikim brojem nesreća u samo 1 godini, od kad je raskrižje rekonstruirano iz klasičnog u dvotračno kružno. U nastavku rada analizirana su 3 varijantna rješenja dvotračnog kružnog raskrižja Rujevica [12]:

1. standardni tip turbo-kružnog raskrižja

2. koljenasti tip turbo-kružnog raskrižja

3. kružno raskrižje "flower“.

Predložene varijante su alternativni načini rekonstrukcije dvotračnih kružnih rotora. Kod svih varijanti poštivani su postojeću uvjeti odvijanja motoriziranog prometa (zadržani su svi smjerovi kretanja), dok je kod nemotoriziranog prometa, zbog malog broja pješaka na pješačkom prijelazu na privozu 4, taj pješački prijelaz u predloženim varijantama izostavljen [12].

Kako bi se odabralo optimalno rješenje za rekonstrukciju raskrižja, svaka od tri varijante analizirana je kroz unaprijed definirane kriterije:

- broj i vrste konfliktnih točaka

- kapacitet raskrižja

- provoznost raskrižja

- provozna brzina. 


\subsection{Predložena varijantna rješenja}

Prvo predloženo rješenje, standardni tip turbo-kružnog raskrižja, zadržao je isti broj prometnih traka na svim privozima. Neposredno prije svakog ulaza i izlaza, na privozima s dvije trake postavljeni su delineatori radi razdvajanja prometa i onemogućenja prestrojavanja u blizini samog raskrižja (Slika 6) [12].

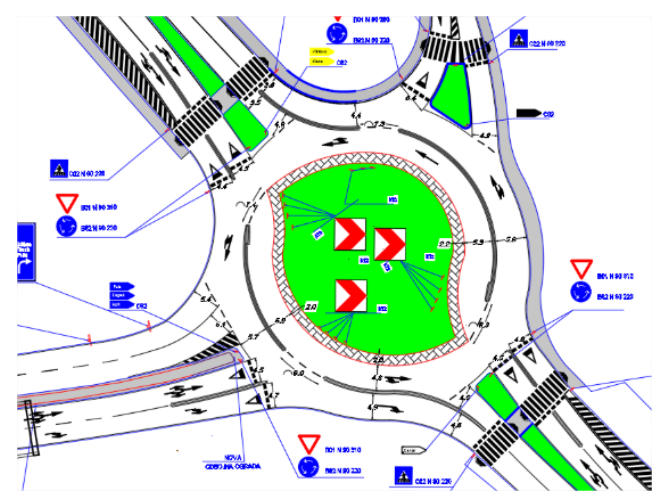

Slika 6. Varijanta 1- standardno turbo kružno raskrižje [12]

Druga varijanta je koljenasti tip turbo kružnog raskrižja, koji omogućuje lijevim skretačima iz privoza 1 (Rijeka) da koriste obje kružne trake raskrižja kako bi izveli manevar lijevog skretanja, a sve zbog većeg prometnog opterećenja iz privoza $1 \mathrm{u}$ privoz 4 (Slika 7). Također, i desni skretači iz privoza 3 , za razliku od prvog rješenja, za izlaz u privoz 4 mogu koristiti dvije trake, također zbog većeg prometnog opterećenja iz privoza 3 u privoz 4 .

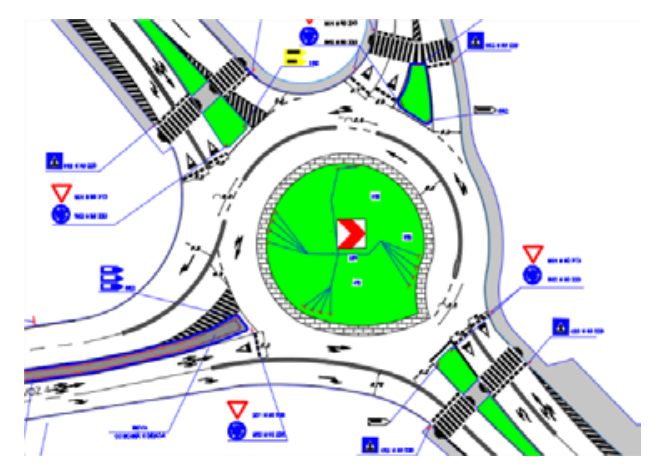

Slika 7. Varijanta 2- koljenasti tip turbo-kružnog raskrižja [12] 
Trake na ulazim i izlazima te u kružnom toku odvojene su delineatorima kako bi se uklonila konfliktna točka preplitanja neposredno prije i u samom raskrižju. Kod ove varijante, radi lakšeg odabira smjera kretanja na privozu 2 , dodana je dodatna traka na ulazu u raskrižje te je stoga sam privoz rekonstruiran na način da je nešto širi u odnosu na prethodno i postojeće rješenje [12].

Treća varijanta je prenamjena sadašnjeg dvotračnog kružnog raskrižja u kružno raskrižje "flower" (Slika 8). Ovakvo rješenje nudi desnim skretačima korištenje „ekskluzivne“ trake za desno skretanje na svakom privozu. U slučaju krivog odabira i ne korištenja te desne trake, vozila koja uđu u kružno raskrižje još uvijek mogu izvršiti manevar desnog skretanja na prvom izlazu. Svaka „pritisnuta“ traka za skretanje udesno odvojena je od kružnog traka razdjelnim (ozelenjenim) otokom, što povećava sigurnost na raskrižju [12].

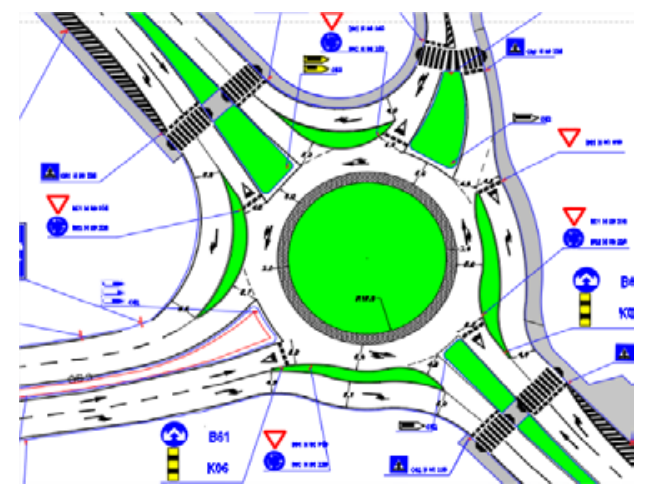

Slika 8. Varijanta 3 - kružno raskrižje "flower" [12]

\subsection{Analiza varijanti prema kriteriju broja i vrste konfliktnih točaka}

Razina sigurnosti prometa analizirana je kroz broj i vrstu konfliktnih točaka koje se javljaju na predloženim varijantama (Slika 9) [12].
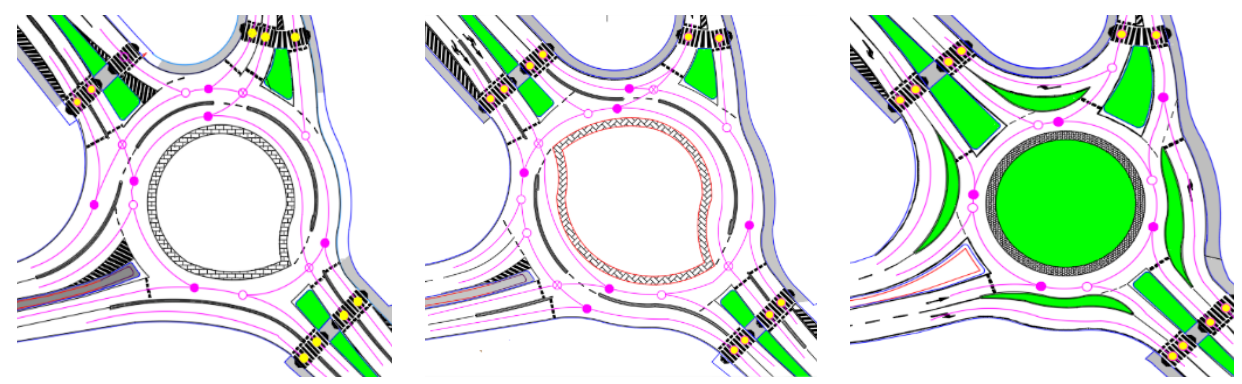

Slika 9. Konfliktne točke na predloženim varijantnim rješenjima [12] 
U Tablici 2 prikazana je usporedba sve 3 varijante, prema broju i vrsti konfliktnih točaka. Usporedbom se može zaključiti da je u pogledu sigurnosti (te potencijalnih prometnih nesreća na raskrižju) najbolje rješenje kružno raskrižje „flower", odnosno Varijanta 3 zbog ukupno najmanjeg broja potencijalnih konfliktnih točaka, zbog nepostojanja konfliktne točke križanja, ali i zbog posebnih traka za desne skretače, koje su od raskrižja fizički odvojene razdjelnim otocima [12].

Tablica 2. Broj i vrsta konfliktnih točaka prema varijantnim rješenjima[12]

\begin{tabular}{|c|c|c|c|c|c|}
\hline konfliktne točke & križanje & uplitanje & isplitanje & $\begin{array}{c}\text { konflikt s } \\
\text { pješacima }\end{array}$ & $\begin{array}{c}\text { ukupno } \\
\text { (+ pješaci) }\end{array}$ \\
\hline varijanta 1 & 4 & 6 & 5 & 10 & $15(25)$ \\
\hline varijanta 2 & 3 & 6 & 4 & 9 & $13(22)$ \\
\hline varijanta 3 & 0 & 5 & 5 & 10 & $10(20)$ \\
\hline
\end{tabular}

\subsection{Analiza varijanti prema kriteriju kapaciteta raskrižja}

Za potrebe analize predloženih varijantnih rješenja prema ovom kriteriju koristilo se povećano prometno opterećenje na raskrižju, pri čemu je za projektni period uzet period od 10 godina, uz godišnju stopu prirasta prometa od $1 \%$.

Za proračun kapaciteta turbo kružnih raskrižja koristila se modificirana Bovyjeva jednadžba preporučena Smjernicama [11] prema kojoj su Varijanta 1 i Varijanta 2 zadovoljile ovaj kriterij budući da proračunata zasićenost prometnih traka na ulazu nije prešla 80\% (Tablica 3) [12].

Tablica 3.Kapacitet raskrižja za Varijantu 1 i 2 [12]

\begin{tabular}{|c|c|c|c|c|}
\hline & \multicolumn{2}{|c|}{ lijeva ulazna traka } & \multicolumn{2}{c|}{ desna ulazna traka } \\
\hline privoz & varijanta 1 & varijanta 2 & varijanta 1 & varijanta 2 \\
\hline 1 & $48 \%$ & $25 \%$ & $32 \%$ & $56 \%$ \\
\hline 2 & $32 \%$ & $19 \%$ & - & $12 \%$ \\
\hline 3 & $15 \%$ & $31 \%$ & $40 \%$ & $20 \%$ \\
\hline 4 & $66 \%$ & $61 \%$ & $39 \%$ & $32 \%$ \\
\hline
\end{tabular}

Za slučaj Varijante 3 korišten je računalni program Sidra Intersecton, pri čemu se kružno raskrižje "flower" analiziralo kao standardno jednotračno kružno raskrižje, a prometno opterećenje predviđeno za desno skretanje uzelo kao minimalno budući desni skretači na svim privozima imaju zasebne prometne trake (by-pass) i u pravilu ne ulaze u kružno raskrižje. 
U slučaju Varijante 3, kako je vidljivo iz Slike 10, razina uslužnosti, odnosno kapacitet raskrižja za predviđeno prometno opterećenje nije zadovoljena (razina uslužnosti na privozu 1 je iznimno loša - F) [12].

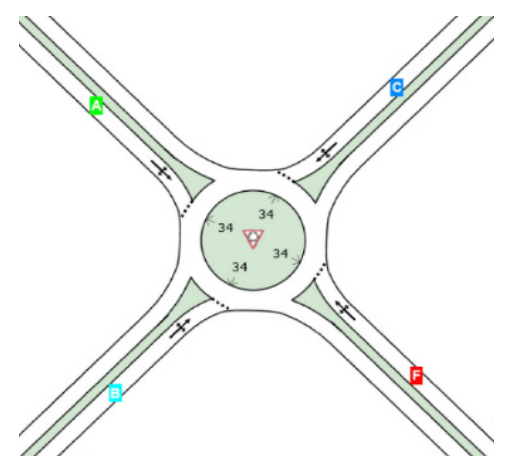

Slika 10. Razina uslužnosti za slučaj Varijante 3 [12]

\subsection{Analiza varijanti prema kriteriju provoznost raskrižja}

Provoznost na raskrižju provjeravana je primjenom računalnog programa AutoTURN.
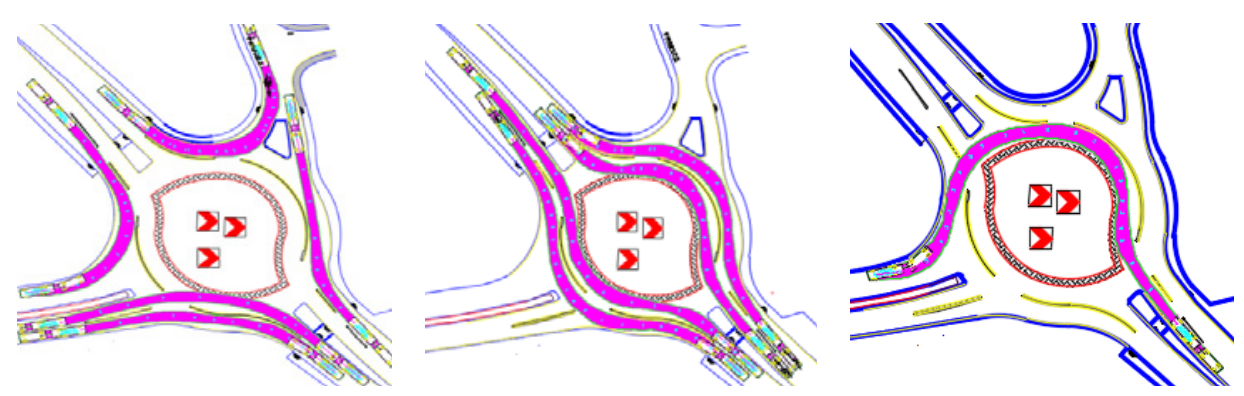

Slika 11. Primjer provjere provoznosti za slučaj Varijante 1 [12]

U slučaju ovog raskrižja, kao mjerodavno vozilo (najveće očekivano) odabran je tegljač s prikolicom, ukupne duljine $18 \mathrm{~m}$. Provoznost je provjerena za sve 3 varijante te za sve dozvoljene smjerove (desne, ravne i lijeve) na privozima. Za provjeru provoznost usvojena je sigurnosna zaštitna udaljenost od $30 \mathrm{~cm}$ od uzdignutih dijelova raskrižja [12].

U slučaju sve tri varijante, ovaj kriterij je zadovoljen. Na Slici 11 prikazana je provjera provoznosti za slučaj Varijante 1. 


\subsection{Analiza kriterija provozne brzine}

Kao posljednji kriterij za vrednovanje predloženih varijanti odabran je kriterij provozne brzine, odnosno najveće teoretske brzine kojom osobno vozilo može proći kroz kružno raskrižje.

Putanja kretanja osobnog vozila pretpostavljena je na udaljenosti 1,5 m od uzdignutih dijelova raskrižja, na ulazu, u sredini raskrižja i na izlazu. Nakon što su aproksimirane putanje kretanja za sve ravne smjerove, očitani su radijusi putanje na ulazu, u sredini raskrižja i na izlazu te su korištenjem izraza za proračun brzine prema Smjernicama $[9,11]$ određene provozne brzine (Slika 12).

Provozna brzina se provjeravala samo za ravni smjer kretanja jer su istraživanja pokazala da su to smjerovi na kojima se u stvarnosti javljaju najveće provozne brzine [13]. Usvojena je preporuka Smjernica [11] za maksimalne očekivane provozne brzine od 35 do $37 \mathrm{~km} / \mathrm{h}$, s kojom su se uspoređivale proračunate provozne brzine. Veće odstupanje od maksimalne preporučene provozne brzine rezultiralo je lošijom ocjenom.

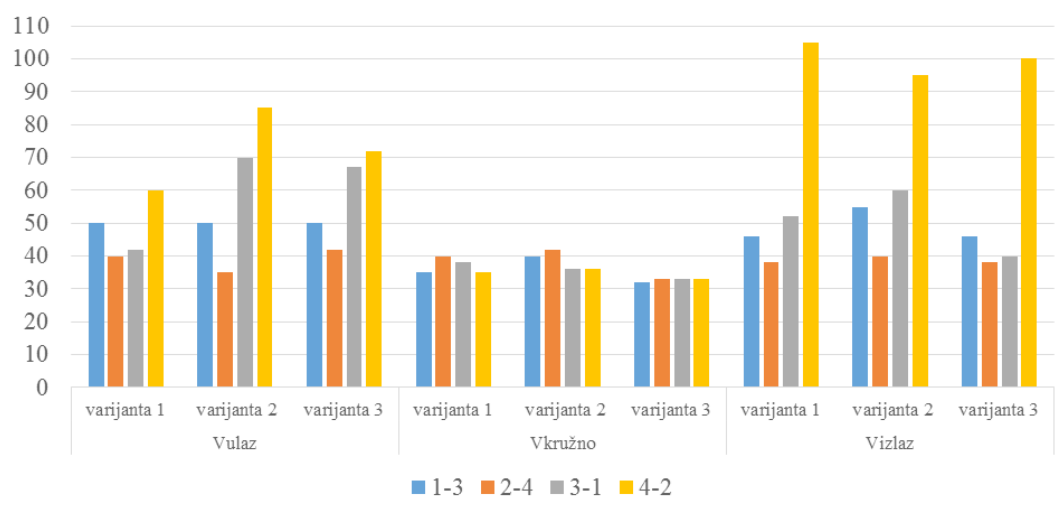

Slika 12. Usporedba provoznih brzina za sve varijante za ravni smjer kretanja kroz raskrižje [12]

\subsection{Odabir optimalne varijante}

Analizira predloženih varijanti kroz navedene kriterije napravljena je na način da se svakoj varijanti za svaki kriterij dodijelila ocjena, a na kraju je, zbrajanjem svih ocjena, odabrano optimalno rješenje kao ono koje ima najveću zbirnu ocjenu. U Tablici 4 prikazane su dodijeljene ocjene po varijantama i kriterijima. Svaki kriterij ocijenjen je ocjenom od 1 do 5, pri čemu veća ocjena znači povoljniju varijantu [12]. Kriterijima nisu pridodavane težine, odnosno, svi su kriteriji tretirani kao jednako važni. 
Tablica 4: Vrednovanje varijanti kroz kriterije [12]

\begin{tabular}{|c|c|c|c|c|c|}
\hline & \multicolumn{5}{|c|}{ Kriterij } \\
\cline { 2 - 6 } & $\begin{array}{c}\text { Konfliktne } \\
\text { Točke }\end{array}$ & Kapacitet & Provoznost & $\begin{array}{c}\text { Provozna } \\
\text { Brzina }\end{array}$ & Ukupno \\
\hline Varijanta 1 & 3 & 4 & 5 & 4 & 16 \\
\hline Varijanta 2 & 4 & 3 & 5 & 3 & 15 \\
\hline Varijanta 3 & 5 & 1 & 5 & 3 & 14 \\
\hline
\end{tabular}

Iz Tablice 4 i Slike 13 vidljivo je da je najbolje ocjenjena Varijanta 1 odnosno standardno turbo kružno raskrižje, dok je flower kružno raskrižje ocjenjeno kao najlošija varijanta.

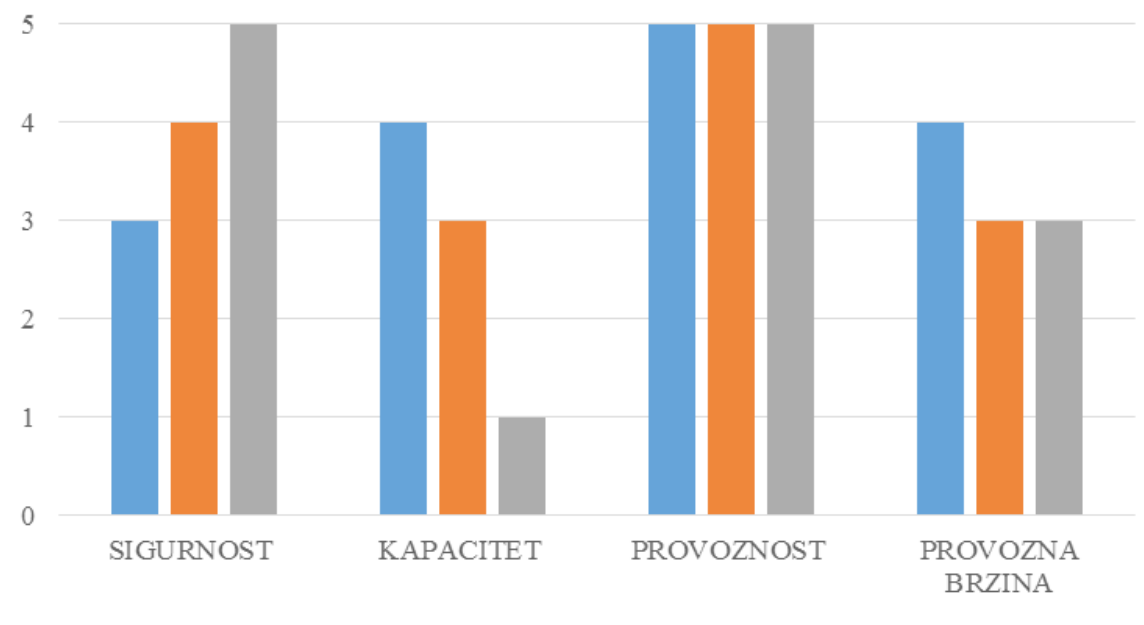

- Varijanta 1 Varijanta 2 Varijanta 3

Slika 13. Usporedba ocjena po kriterijima za svaku varijantu [12]

\section{Zaključak}

U radu je prezentirana analiza postojećeg stanja dvotračnog kružnog raskrižja Rujevica te su predložene tri varijante rješenja njegove rekonstrukcije, a koje su se zatim analizirale multikriterijskom analizom prema unaprijed odabranim kriterijima te je predložena optimalna varijanta.

Postojeće raskrižje analizirano je s aspekta sigurnosti prometa, prema podacima o prometnim nesrećama iz 2017. g., čiji broj i vrsta upućuje da se velik broj nesreća događa prilikom prestrojavanja u samom kružnom kolniku dvotračnog kružnog raskrižja. Razlog tome leži u maloj duljini 
za prestrojavanje (mali vanjski radijus raskrižja te mali razmak između susjednih ulaza i izlaza), no isto tako i u potencijalnoj nesigurnosti vozača koji, s obzirom na mali broj dvotračnih kružnih raskrižja na području grada Rijeke, nisu navikli na njihovu pravilnu upotrebu.

Analiza podataka o prometnom opterećenju i operativnim brzinama pokazala je da su privozi 1, 3 i 4 podjednako prometno opterećeni. Prometno opterećenje na privozu 2 nije mjereno (kao niti brzine) budući da se radi o privozu koji trenutno služi jedino kao pristup trgovačkom centru. Očekivano prometno opterećenje je malo, kao i operativne brzine. Analizom kapaciteta raskrižja na temelju postojećeg prometnog opterećenja i geometrije raskrižja utvrđeno je da raskrižje potpuno zadovoljava u pogledu kapaciteta te da postoji velika rezerva u kapacitetu za postojeću geometriju raskrižja.

Analizirana je i preglednost postojećeg raskrižja, koja je na svim privozima raskrižju kao i na samom kružnom kolniku potpuno zadovoljavajuća.

Ipak, veliki broj prometnih nesreća koje su se dogodile u prvoj godini funkcioniranja dvotračnog kružnog raskrižja, uz čak jedan smrtni ishod, upućuju na nisku razinu prometne sigurnosti na ovom raskrižju. Stoga su analizirana tri varijantna rješenja za rekonstrukciju raskrižja: Varijanta 1standardno turbo-kružno raskrižje, Varijanta 2 - koljenasto turbo-kružno raskrižje te Varijanta 3 - „flower“ raskrižje. Sva odabrana varijantna rješenja su alternativni tipovi kružnih raskrižja, čija je glavna prednost nepostojanje konfliktne točke prestrojavanja u samom kružnom kolniku, a koja se kod postojećeg raskrižja pokazala uzrokom nastanka velikog broja nesreća na raskrižju.

Rješenja su analizirana prema slijedećim jednako važnim kriterijima: kriterij broja i vrste konfliktnih točaka, kriterij kapaciteta, kriterij provoznosti i kriterij provozne brzine.

Ukupno, uzimajući u obzir sve kriterije, optimalnom varijantom pokazala se Varijanta 1, odnosno standardno turbo-kružno raskrižje. U odnosu na odabranu varijantu, Varijanta 2 je lošije ocjenjena zbog većih provoznih brzina na raskrižju, a Varijanta 3 zato što nije zadovoljila kriterij kapaciteta raskrižja.

Primjenom standardnog tipa turbo-kružnog raskrižja postignuta je optimalna ravnoteža između povećanja sigurnosti, što je u ovom slučaju rekonstrukcije prioritetni cilj, i kapaciteta raskrižja.

Zahvala. Ovaj je članak rezultat rada u okviru projekta Razvoj istraživačke infrastrukture na kampusu Sveučilišta u Rijeci (RC.2.2.060001) koji je sufinanciran iz Europskog fonda za regionalni razvoj (EFRR) $i$ Ministarstva znanosti, obrazovanja i sporta $R H$. Objava ovog rada je podržan od strane Sveučilišta u Rijeci u okviru projekta „Prometna infrastruktura u funkciji održive urbane mobilnosti” (uniri-tehnici-18-143) 


\section{Literatura}

[1] Mensah, S., Eshragh, S., Faghri, A. Roundabouts and Sustainable Intersection Design, $3^{\text {rd }}$ International Conference on Roundabouts, Carmel, Indiana US, 2011.

[2] Isebrands, H. Crash Analysis of Roundabouts at High-speed Rural Intersection, Transportation Research Record, Journal of the Transportation Research Board, Washington, 1-7, 2009.

[3] Várhelyi, A. The Effects of Small Roundabouts on Emissions and Fuel Consumption: a Case Study. Transportation Research Part D: Transport and Environment 7: 65-71, 2002

[4] Brüde, U., Larsson, J. What Roundabout Design Provides the Highest Possible Safety. VTI Meddelande 864 \& 865, Swedish National Road and Transport Research Institute VTI., 1999.

[5] Minnen, J. van Rotondes en voorrangsregelingen II. Uniformering voorrangsregelingen op oudere pleinen, veiligheid fietsvoorzieningen en tweestrooks rotondes. SWOV-report R-98-12. SWOV, Leidschendam, 1998.

[6] Mauro R, Branco F, Comparative Analysis of Compact Multilane Roundabouts and Turbo-Roundabouts, Journal of Transportation Engineering,136(4), (2010), 316-322

[7] Tollazzi, Tomaž, et al. Comparative Analysis of Four New Alternative Types of Roundabouts: "Turbo", "Flower", "Target" and "Four-Flyover" Roundabout. Periodica Polytechnica Civil Engineering 60.1 (2016): 51-60.

[8] Legac, I.: Raskrižja javnih cesta, Fakultet prometnih znanosti, Zagreb, 2007

[9] Deluka-Tibljaš, Aleksandra, et al. Smjernice za projektiranje kružnih raskrižja na državnim cestama. Građevinski fakultet Sveučilišta u Rijeci, 2015.

[10] Tomaž Tollazzi; Alternative Types of Roundabouts 2015.

[11] Tollazzi, T., et al, Smjernice za projektiranje kružnih raskrižja sa spiralnim tokom kružnog kolnika na državnim cestama. Sveučilište u Rijeci, Građevinski fakultet Rijeka, Rijeka, 2014.

[12] Rutko, Ivan. Varijantna rješenja dvotračnog kružnog raskrižja Rujevica. Diplomski rad. Sveučilište u Rijeci, Građevinski fakultet u Rijeci, 2019.

[13] Šurdonja, Sanja. Numerički model provozne brzine kružnoga raskrižja, 2017., doktorska disertacija, Građevinski fakultet Sveučilišta u Zagrebu, Zagreb 